\title{
The Use of Sistem Pembelajaran Daring (SIPDA) as an Online Learning Management System on Learning Outcomes of Financial Accounting Subject: A Mediation Effect of Learning Motivation
}

\author{
Andri Zainal ${ }^{1, *}$, Tessa Aprilia Marantika Tampubolon ${ }^{1}$, Rini Herliani ${ }^{1}$, Sondang \\ Aida Silalahi ${ }^{1}$, Jufri Darma ${ }^{1}$ \\ ${ }^{1}$ Department of Accounting Education, Faculty of Economics, Universitas Negeri Medan, Medan, Indonesia \\ ${ }^{*}$ Corresponding author. Email: andrizainal@unimed.ac.id
}

\begin{abstract}
This study aims to determine the effect of SIPDA on Learning Outcomes through Student Learning Motivation taking the Financial Accounting subject. This study population was 70 students in the Accounting Education Department of Faculty of Economics of Universitas Negeri Medan (UNIMED) and used as respondents. The questionnaire consisted of 18 items for SIPDA and 6 question items for learning motivation. This study applies the outer model test, the inner model test, the direct influence hypothesis test, and the indirect hypothesis test using the SmartPLS 3.0 program. The result of data analysis shows that: (1) There is a negative and significant influence between the use of SIPDA on the learning outcomes of accounting class 2019 students with a path coefficient of -0.371 and P-value <0.05, which is 0.025 and the value of T Statistics > 1.96 namely 2.243; (2) There is a positive and significant influence between the use of SIPDA on students' learning motivation for Accounting Education Class of 2019 with a path coefficient of 0.743 and a P-Value $<0.05$ which is equal to 0.000 and a value of T Statistic $>1.96$ which is 13.568; (3) There is a positive and significant influence between learning motivation on student learning outcomes of Accounting Education Class of 2019 with a path coefficient of 0.373 and a P-Value $<0.05$ which is equal to 0.029 and a value of T Statistics $>1.96$ which is 2.188. (4) There is a positive and significant influence between the use of SIPDA on learning outcomes through students' learning motivation for Accounting Education Class of 2019 with a value of 0.277 with a P-Values $<0.05$, which is equal to 0.045 , and a Statistical T value> 1.96 which is 2.014 .
\end{abstract}

Keywords: Learning Management System, SIPDA, Constructivism Theory, Learning Outcomes, Accounting Education

\section{BACKGROUND OF THE STUDY}

The use of information technology is needed to support teaching and learning activities, one of which is using an online learning system (elearning). Learning using an online system or elearning is very good for use in the learning process supported by lecture facilities such as a stable internet network and the availability of hot spots, making it possible to use the e-learning system. The concept of e-learning is an alternative for students and lecturers to develop themselves and efforts to increase student motivation and learning outcomes. More specifically, E-learning is a combination of information, interaction, and educational communication, core elements in achieving success [1]. Lectures using an online learning system are a combination of distance and face-to-face learning using internet technology to access learning material anywhere and anytime.

Based on constructivism theory, a theory gives freedom to humans who want to learn or seek their needs to find these wants or needs. Humans learn to find their competencies, knowledge, or technology, and the things needed to develop themselves [2]. Knowledge is not a set of facts, concepts, and rules ready to be put into practice. Humans must first construct this knowledge and give meaning through real experiences. The constructivism theory explains that by using technology, humans can develop knowledge within themselves, for example, by using an online learning system.

The use of online learning systems encourages students to interact with learning resources, namely the internet, actively. The more actively students use learning resources, the more and more quickly they can shape their knowledge. This theory's important concept is that students can actively build and develop their knowledge based on their own experiences. 
UNIMED or Medan State University has built an internet-based learning system or e-learning useful for optimizing information technology in supporting learning activities through the Online Learning System (SIPDA). Learning using SIPDA is an effort to support various lecturers, students, and various parties involved in the learning process, such as delivering material, giving quizzes or daily tests, and assessments. As explained at the State University of Medan (www.unimed.ac.id), online learning media or e-learning has been used since 2007. The use of SIPDA began to be effectively used in the even semester of 2018. Previously, UNIMED used SIPOEL (Electronic Learning Portal System), which is then updated to adapt to the latest technological developments. This online system's learning process is carried out through the Learning Management System (LMS) based on the opensource CMS applicable in the mobile device. The application's flexibility makes it easier for students in the learning process and obtaining material without having to face to face in class.

SIPDA is also applied to the Accounting Education study program, one of the Faculty of Economics departments, Medan State University. Initial observations made in the Accounting Education study program show that SIPDA is still not effectively used in every generation. However, the use of SIPDA in batch 2019 is often used, even though it has not been optimal in utilizing the available features. The use of SIPDA is used to share material, send assignments, and work on questions when the lecturer cannot attend class. One of them is in the Financial Accounting course, a compulsory subject in the Accounting Education Study Program that students must complete, which is useful as a basis for prospective accounting teachers' knowledge. We conducted an observation on the use of SIPDA in terms of ease of use and flexibility in generating course material. However, students' obstacles are accessing SIPDA in the environment around the campus, where the internet connection is not smooth, and the server has an error, so it takes a long time for access to enter it. These particular problems make many students not on time to complete assignments given by lecturers through SIPDA. It is also not optimal to utilize every feature available in SIPDA, such as discussion forums, messages, site news, learning plants, and various other features that are still unknown to students. Eventually, it affects student motivation to use SIPDA that further impacts learning outcomes.

Based on research conducted by [3] that the use of LMS called SIMARI as an implementation of elearning based learning for students at Lambung Mangkurat University significantly improves student learning outcomes. This research is in line with the research by [4], which shows that the higher the use of e-learning by Yogyakarta State University students, the student's learning motivation will increase, and student learning achievement will also increase. Furthermore, [5] studies the significant relationship between e-learning on student motivation; students who are more motivated to learn will be more likely to be involved and succeed in achieving learning goals. The study aimed to examine the direct and indirect effects of learning motivation between the influence of the use of SIPDA UNIMED on learning outcomes in financial accounting courses and students of the Accounting Education study program at the Faculty of Economics, State University of Medan.

\section{LITERATURE REVIEW}

\subsection{Online Learning System: Its Effect on Learning Motivation and Outcomes}

The online learning system or e-learning is a learning process that uses electronic media connected to the internet network as a learning system. According to [6], e-learning is a learning process that uses or utilizes information and communication technology (ICT) as a tool that can be used anytime and anywhere so that it can overcome time constraints and space. E-learning can support and is suitable for use as a learning tool to access information, fill in learning content, communication, interaction, assessment activities for students and teachers [6].

In its development, an online learning system (elearning) using a Learning Management System (LMS) supports various activities, including administration, delivery of learning materials, assessment assignments with quizzes, tracking and monitoring, collaboration, and communication. The online learning system or e-learning is a learning process carried out using electronic media connected to the internet network to access information about learning materials, assessment activities, and communication.

The use of online learning systems is one effort that can be done to overcome problems and make it easier for students to access lecture materials [1], communicate with each other and conduct online discussions, and obtain tutorial sharing assistance by lecturers available on online learning system media. The online learning system can optimize the interaction between lecturers and students through discussion forums contained in the media. The online learning process focuses on students, empowers student autonomy and independence, and is based on the principles of four main streams, namely behaviorism, cognitivism, and connectivity. Students follow the learning process delivered via the network and obtain digital material, do assignments via the network, receive and collect assignments over the network, obtain other information through mailing lists, and others. The principles of learning in the context of the Online 
Learning System are based on the principle of open education, so that it can provide learning freedom for students across time and space, as well as the principle of integration in the implementation of learning, especially online learning that takes into account quality standards of achievement learning to allow the credit recognition system between universities [7].

\subsection{LMS IN UNIMED: THE SIPDA}

The online learning system or e-learning has been used at Unimed since 2007, known as SIPOEL (System Portal Electronic Learning). However, along with technological developments, the SIPOEL learning system, which still uses the old system, is then adjusted to the latest technology and replaced with the latest system, namely SIPDA (Online Learning System). Unimed SIPDA began to be effectively used starting in the even semester of 2018. The use of SIPDA can be accessed through the sipda.unimed ac.id page and is available in the form of an Android version application. The SIPDA Unimed application is open source-based and supports mobile devices that provide a full range of features tailored to the online learning process's needs. The purpose of updating the SIPDA Unimed is to be used efficiently and accelerates the learning process. Besides, the use of SIPDA Unimed is also expected to form competent graduates by utilizing the latest technology. Based on the description above, it can be concluded that the use of SIPDA affects student learning outcomes through learning motivation.

H1

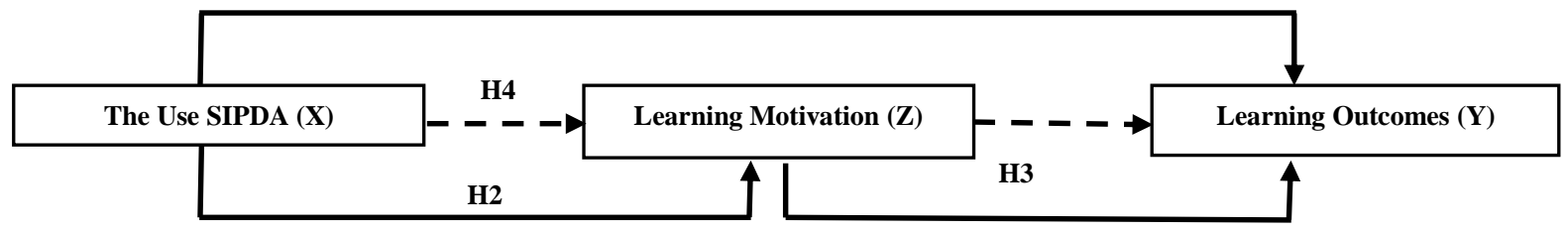

Figure 1. Research Model

\section{RESEARCH METHOD}

The population in this study were all students of the Accounting Education Study Program Class of 2019, which consisted of 2 classes with 70 students. By paying attention to the sample size, the entire population is used as a unit of analysis where both classes have used SIPDA UNIMED in learning Financial Accounting courses.

The data analysis technique used in this study was Partial Least Square (PLS). PLS is a structural equation modeling (SEM) model using an approach based on variance or component-based structural equation modeling. In particular, the data analysis referred to includes testing the outer model (convergent validity, discriminant validity, and composite reliability); inner model (R-square, Fsquare, and Estimate for Path Coefficient) [8]. The analysis of the data used in this study using SmartPLS software. The SmartPLS uses the bootstrapping method or random multiplication. Therefore, the assumption of normality is not a problem. Also, SmartPLS does not require a minimum number of samples so that it can be applied to research with a small sample size [8].

\section{DISCUSSION AND ANALYSIS}

The following shows the results of the structural analysis of the inner model.

Table 1. The Result of Inner Structural Model

\begin{tabular}{|c|c|c|c|}
\hline \multicolumn{3}{|l|}{ R-Square } & \\
\hline Variables & R-Square & R-Square Adjusted & \\
\hline Learning Outcomes (Y) & 0.071 & 0.043 & \\
\hline Learning Motivation $(\mathrm{Z})$ & 0.552 & 0.546 & \\
\hline \multicolumn{4}{|l|}{ F-Square } \\
\hline & Learning Outcomes (Y) & Learning Motivation (X) & The use of SIPDA $(\mathrm{X})$ \\
\hline \multicolumn{4}{|l|}{ Learning Outcomes (Y) } \\
\hline Learning Motivation (Z) & 0.067 & & \\
\hline The use of SIPDA (X) & 0.066 & 1.233 & \\
\hline
\end{tabular}

\begin{tabular}{|l|l|}
\hline Estimate Path Coefficients \\
\hline & P Values \\
\hline The use of SIPDA (X) -> Learning Motivation (z) -> Learning Outcomes (Y) & $\mathbf{0 . 0 4 5}$ \\
\hline
\end{tabular}




\subsection{Direct Effect of the Use of SIPDA on Learning Outcomes}

The analysis results show that the effect of SIPDA on learning outcomes has a negative effect on the path coefficient value of -0.371 and significant with a P-Values value $<0.05$, namely 0.025. This result shows that the direct effect of SIPDA on learning outcomes is in the opposite direction. If the value of using SIPDA increases, the value of learning outcomes will decrease. The result is in contrast to research conducted by [3], which shows that learning outcomes will increase with elearning. Likewise, research conducted by [4] and [5] shows a positive effect on the use of e-learning on learning outcomes.

However, this study's results are in line with [9] research, which partially shows that e-learning has no positive effect on student learning outcomes. This means that e-learning does not affect learning outcomes because the application of e-learning is still superficial; the availability of the material presented is minimal. Other factors outside of elearning affect student learning outcomes more.

In this study, the use of SIPDA in financial accounting courses is quite good but not very effective in improving learning outcomes. This is because there are several things that are not obtained in online learning, such as face-to-face learning. Learning financial accounting requires expertise in analyzing information, making decisions, and critical analysis, so that it takes a lot of practice and work on case study questions to develop skills in the field of accounting [10]. There is also a need for intense interaction between lecturers and students in the financial accounting learning process that can be done virtually face-to-face.

\subsection{Direct Effect of the Use of SIPDA on Learning Motivation}

The data analysis results show the effect of SIPDA on learning motivation that has a positive effect on the path coefficient value of 0.743 and significant with a P-Value $<0.05$, namely 0.000 . The direct effect of SIPDA on learning motivation is unidirectional. These results indicate that the higher the use of SIPDA can increase student motivation.

This hypothesis test result supports [4], which shows that e-learning has a significant effect on learning motivation. As [6] states, the use of learning media in the learning and teaching process can arouse new desires and interests, generate motivation and stimulation of learning activities, and have a psychological influence on students.

Furthermore, the results of research conducted by [5] highlighted the significant relationship between e-learning and student motivation. In his research, it is said that students will be motivated when they have an interest in something unique and exciting to learn. This study's results are also by research conducted by [11], which shows a relationship between the use of e-learning and learning motivation with a correlation coefficient value of 0.625 , which means that it has a relationship and a regression coefficient $\mathrm{X}$ of 0.737 .

\subsection{Direct Effect of the Use of Learning Motivation on Learning Outcomes}

The data analysis results show that the effect of SIPDA on learning motivation has a positive effect on the path coefficient value of 0.373 and significant with a P-value $<0.05$, namely, 0.029. It underlines the direct effect of learning motivation on learning outcomes is unidirectional. The results of these studies indicate that the higher the student's learning motivation, the more the learning outcomes will increase.

The function of learning motivation is to give strength to learning power, improve the quality of learning, and become a driving force to be able to learn continuously [2]. Thus, if someone has a strong motivation to learn in him, his learning will be better and can achieve maximum learning outcomes. In line with [12] research, which shows the relationship between learning motivation variables and learning outcomes variables goes one way. If the learning motivation variable increases, the learning outcome variable will also increase, and vice versa.

\subsection{The Mediating Effect of Learning Motivation on the Relationship between the Use of SIPDA and Learning Outcomes}

The hypothesis test result shows that there is an indirect influence between the SIPDA variable on learning outcomes through learning motivation, namely with a value of 0.277 with a P-Values value of $0.045<0.05$ (significant). So learning motivation indirectly mediates the influence of SIPDA on learning outcomes. From the results of this study, it can be seen that to improve learning outcomes indirectly; students must have learning motivation in students using learning media, namely SIPDA.

These results are in line with (4) research, which shows that the higher the use of e-learning, the learning motivation of students will increase, the learning achievement will also increase. The finding is also in line with the constructivism theory, which assumes that students build their knowledge from their own learning experiences. The formation of knowledge lies in individuals' activeness in shaping their knowledge [13]. Students can construct their knowledge, facilitated by online learning.

\section{CONCLUSION AND IMPLICATION}

In general, the use of SIPDA UNIMED has a positive and significant impact on learning 
motivation and learning outcomes of Class 2019 Accounting Education students at the Faculty of Economics, State University of Medan. The higher the use of SIPDA, the learning motivation and learning outcomes will increase because the financial accounting course requires practice and practice working on questions and more intense interaction between students and lecturers. Also, the learning motivation variable mediates the effect of using SIPDA on learning outcomes through the learning motivation of Class 2019 Accounting Education students.

In particular, as the developer of SIPDA, UNIMED can improve the quality of SIPDA, which is useful in the learning process and provides education on the use of the features available in SIPDA. Students can be more focused and understand in their use, and students become more motivated in using SIPDA and improving their learning outcomes.

\section{REFERENCES}

[1] D. Darmawan, Pengembangan E-learning Teori dan Desain. Bandung: PT Remaja Rosdakarya, 2014.

[2] M. Thobroni. Belajar dan Pembelajaran. Yogyakarta: Arr-Ruzz Media, 2015.

[3] M. Meliyani, S. Supriyanto, Muhammad Rahmattullah. Pengaruh Pemanfaatan Simari sebagai Implementasi Pembelajaran Berbasis E-Learning terhadap Hasil Belajar Mahasiswa Prodi Pendidikan Ekonomi, Jurnal Pendidikan Ilmu Sosial 29.1, 2019. pp. 1-8. DOI: https://doi.org/10.23917/jpis.v29i1.8232

[4] L. Darliah. Pengaruh Kualitas Informasi Dan Penggunaan E-Learning Terhadap Prestasi Belajar Mahasiswa Pendidikan Ekonomi Fe UNY Dengan Motivasi Belajar Sebagai Variabel Intervening. Jurnal Pendidikan dan Ekonomi, 5(2). 2016. pp. 150-157.

[5] S. R. Harandi, Effects of e-learning on Students Motivation. Procedia-Social and Behavioral Sciences, 181, 2015. 423-430. DOI: https://doi.org/10.1016/j.sbspro.2015.04.905

[6] A. P. Sari, A. P., A. Setiawan. The Development of Internet-Based Economic Learning Media using Moodle Approach. International Journal of Active Learning. 2018. pp. 100-109. DOI: https://doi.org/10.15294/ijal.v3i2.13449
[7] Ristekdikti. Panduan Proses Pembelajaran Daring (SPADA 2019). Jakarta. Available online

https://lmsspada.kemdikbud.go.id/pluginfile.p hp/98994/mod_resource/content/1/PANDUA N\%20PROSES-edit.pdf

[8] I. Ghozali, I., H. Latan. Partial Least Square Konsep Teknik dan Aplikasi Menggunakan Program SmartPLS 3.0. 2015. Semarang: Badan Penerbit Universitas Diponegoro.

[9] S. Shofiyah. Pengaruh Penggunaan Android dan E-learning Terhadap Hasil Belajar Mata Pelajaran IPS Siswa Kelas VIII SMPN 3 Kepanjen Malang. 2016. Skripsi. Universitas Islam Negeri Maulana Malik Ibrahim Malang.

[10] L. Latifah L, N. Susilowati Inovasi Pembelajaran Akuntansi Berbasis Blended Learning. Dinamika Pendidikan. 2011, 6(2), pp. 222-32. DOI: https://doi.org/10.15294/dp.v6i2.5113

[11] A. Aurora, H. Effendi. Pengaruh Penggunaan Media Pembelajaran E-Learning Terhadap Motivasi Belajar Mahasiswa di Universitas Negeri Padang. Jurnal Teknik Elektro dan Vokasional. (2019). 5(2). pp. 11-16. DOI : https://doi.org/10.24036/jtev.v5i2.105133

[12] R. Ricardo, I. Meilani. Impak Minat dan Motivasi Belajar Terhadap Hasil Belajar Siswa. Jurnal Pendidikan Manajemen Pendidikan, 2017. 2(2). pp. 188-201. DOI: https://doi.org/10.17509/jpm.v2i2.8108

[13] M. L. Jeffrey, J. Milne, G. Suddaby. A. Higgins. Blended learning: How teachers balance the blend of online and classroom components. Journal of Information Technology Education: Research, 2014. 13, 121-140. Retrieved from http://www.jite.org/documents/Vol13/JITEv1 3ResearchP121-140Jeffrey0460.pdf 